Abstract-Abundance and harvest of rainbow smelt (Osmerus mordax) in the northwest Atlantic Ocean have declined sharply in recent decades, with a concurrent reduction in the historic geographic range of this species. These declines have occurred while management responses have been limited by information gaps on the life history of this species. We assessed reproductive attributes of rainbow smelt caught in marine waters during winter and compared their size and age characteristics to those of fish sampled from spring spawning runs in 4 coastal rivers in Massachusetts. Total fecundity of rainbow smelt was 4880-51,651 oocytes. Fecundity was positively related with total length (TL), total weight, ovarian weight, and age. Immature rainbow smelt were rarely caught during spawning runs but composed $10 \%$ of the marine samples. This observation, a maturity ogive for rainbow smelt from marine waters, and differences in TL of age-1 fish between marine and river samples confirm that age-1 rainbow smelt are not fully recruited to spawning runs. Samples from spawning runs had a higher proportion of age-1 rainbow smelt, a lower proportion of those age 3 or older, a higher instantaneous rate of total mortality, and a lower number of eggs produced per recruit than have been previously documented for rainbow smelt-all indications of declining population health.

Manuscript submitted 1 August 2018. Manuscript accepted 5 July 2019. Fish. Bull. 117:151-168 (2019). Online publication date: 17 July 2019. doi: 10.7755/FB.117.3.3

The views and opinions expressed or implied in this article are those of the author (or authors) and do not necessarily reflect the position of the National Marine Fisheries Service, NOAA.

\title{
Fecundity and reproductive life history of anadromous rainbow smelt (Osmerus mordax) in coastal waters of Massachusetts
}

\author{
Bradford C. Chase (contact author) ${ }^{1}$ \\ Scott Elzey ${ }^{2}$ \\ Sara M. Turner ${ }^{1}$ \\ Matt H. Ayer ${ }^{2}$ \\ Email address for contact author: brad.chase@mass.gov \\ 1 Massachusetts Division of Marine Fisheries \\ 836 South Rodney French Boulevard \\ New Bedford, Massachusetts 02744 \\ 2 Massachusetts Division of Marine Fisheries \\ 30 Emerson Avenue \\ Gloucester, Massachusetts 01930
}

The northwest Atlantic Ocean, including the Gulf of Maine, is among the fastest-warming marine areas in the world (Hare et al., 2016). The rainbow smelt (Osmerus mordax) is an anadromous species that has adapted to thrive in cold-water environments (Driedzic and Ewart, 2004; Driedzic and Short, 2007) and is restricted to the northwest Atlantic Ocean. Improvements are needed in our understanding of the life history and population dynamics of rainbow smelt to determine conservation strategies. The rainbow smelt is a small, shortlived fish that matures in coastal waters and migrates in spring to spawn in coastal rivers. This species formerly supported important commercial and recreational fisheries in the Canadian Maritime provinces and the U.S. waters of the Gulf of Maine (Goode, 1884; Kendall, 1926; Enterline et al., 2012). Rainbow smelt fisheries in Massachusetts were regulated for rod-and-reel harvest only for most of the 20th century. For estuary ice-shack fisheries and fall shoreline fisheries, popular more than 30 years ago, participation and harvest have declined to low levels $\left(\right.$ Chase $\left.^{1}\right)$. Rainbow smelt can be essential to inland aquatic food webs (Kircheis and Stanley, 1981; O'Gorman et al., 1987; Sayers et al., 1989) and are considered important prey for a variety of fish and wildlife species in coastal rivers and marine habitats (Scott and Scott, 1988).

Overall, diadromous fish species have experienced severe population declines since the 18th century with most species at historically low levels of abundance in the northwest Atlantic Ocean (Limburg and Waldman, 2009). Anadromous rainbow smelt have experienced a substantial contraction of the southern part of their historical geographic range (Enterline et al., 2012), but details on their population dynamics and life history remain poorly known. In response to concerns over populations of rainbow smelt in New England, NOAA listed anadromous rainbow smelt as a species of concern in 2004 (Federal Register, 2004).

\footnotetext{
${ }^{1}$ Chase, B. C. 2006. Rainbow smelt (Osmerus mordax) spawning habitat on the Gulf of Maine coast of Massachusetts. Mass. Div. Mar. Fish. Tech. Rep. TR-30, 173 p. [Available from website.]
} 


\section{Table 1}

Summary of key information from previous studies of the fecundity of rainbow smelt (Osmerus mordax) in coastal waters of Massachusetts and Canada and in the Great Lakes. Data provided are location, type of population, total number of samples $(n)$, and ranges for size, measured as millimeters in total length (TL), and fecundity, measured as the number of mature oocytes prior to spawning.

\begin{tabular}{|c|c|c|c|c|c|}
\hline Citation & Location & Type & $n$ & Size (mm TL) & $\begin{array}{c}\text { Fecundity } \\
\text { (no. of oocytes) }\end{array}$ \\
\hline McKenzie, 1964 & New Brunswick & Anadromous & 9 & $127-209$ & $8500-69,600$ \\
\hline Clayton, 1976 & Massachusetts & Anadromous & 11 & $127-204$ & $7038-44,241$ \\
\hline Chen, 1970 & Grande Riviere, Quebec & Anadromous & 48 & $160-225$ & $21,390-75,570$ \\
\hline Bailey, 1964 & Lake Superior & Landlocked & 10 & $185-224$ & $21,534-40,894$ \\
\hline Chen, 1970 & Matamek Lake, Quebec & Landlocked & 64 & $202-280$ & $14,269-75,944$ \\
\hline Chen, 1970 & Lake Erie, Ontario & Landlocked & 93 & $115-194$ & $2700-37,520$ \\
\hline Chen, 1970 & Lake Ontario, Ontario & Landlocked & 172 & $109-256$ & $4766-100,780$ \\
\hline Luey and Adelman, 1984 & Lake Superior & Landlocked & 208 & $145-225$ & $4323-50,418$ \\
\hline
\end{tabular}

In response, a regional conservation plan for rainbow smelt in the Gulf of Maine was developed and documented range-wide declines in harvest records for rainbow smelt (Enterline et al., 2012). Similar concerns have been expressed for fisheries and populations of rainbow smelt in Canada (Trencia et al., 2005; Verreault et al., 2012).

Anadromous rainbow smelt reproduce during spring spawning runs in freshwater riffles a short distance above tidal influence (Kendall, 1926; McKenzie, 1964; Murawski et al., 1980; Chase $^{1}$ ). Female rainbow smelt deposit demersal, adhesive eggs that incubate for 1-4 weeks, depending on water temperature (McKenzie, 1964; Chase et al. ${ }^{2}$ ), and hatched larvae are transported to estuarine waters. Female rainbow smelt complete spawning in 1-4 nights, whereas males remain longer on spawning grounds (Marcotte and Tremblay, 1948; Murawski et al., 1980). This brief female spawning period is consistent with reports that female rainbow smelt possess a single set of mature oocytes, with no differences in oocyte size and maturity among ovary locations (Chen, 1970; Clayton, 1976).

Rainbow smelt occur in anadromous and landlocked populations in northeastern North America, with differences in life history. Landlocked rainbow smelt are present naturally in some coastal lakes; however, most populations were introduced to the Great Lakes and many smaller watersheds early in the 20th century (Van Oosten, 1937; Evans and Loftus, 1987; and Mercado-Silva et al., 2006). Landlocked rainbow smelt grow slower and are smaller than anadromous rainbow smelt, and they mature at an older age (Bailey, 1964; Luey and Adelman, 1984; O’Malley et al., 2017). The maturity schedule and fecundity of landlocked rainbow smelt have been related to high recruitment variability (O'Gorman et al., 1987; Gorman, 2007; Stritzel Thomson et al., 2011), and comparable information on

\footnotetext{
${ }^{2}$ Chase, B. C., J. H. Plouff, and M. Gabriel. 2008. An evaluation of the use of egg transfers and habitat restoration to establish an anadromous rainbow smelt spawning population. Mass. Div. Mar. Fish. Tech. Rep. TR-33, 16 p. [Available from website.]
}

reproduction of anadromous rainbow smelt is not available. Fecundity has been reported for anadromous populations of rainbow smelt, but with small sample sizes (combined number of samples $[n]=68$, among 3 studies: McKenzie, 1964; Chen, 1970; and Clayton, 1976). Fecundity of landlocked rainbow smelt has been studied in the Great Lakes (Bailey, 1964; Chen, 1970; Luey and Adelman, 1984), with fecundities ranging from 2700 to 100,780 eggs (Table 1).

With a paucity of population data and gaps in basic life history information for anadromous rainbow smelt, limited support is available for management decisions on population status and vulnerability. Here, we aim to advance the understanding of the reproductive life history of rainbow smelt with improved estimates of fecundity, of size and age at maturity, and of length and age composition during spawning runs. We also estimated mortality and eggs per recruit and compared the results to historical data for rainbow smelt. A key assumption was that the apparent changes in abundance of rainbow smelt would be reflected in truncated age structure and increasing mortality. To achieve these objectives, rainbow smelt were sampled as part of an inshore winter trawl survey prior to spawning and later in 4 coastal rivers in Massachusetts during their spawning migrations.

\section{Materials and methods}

Historically, the range of rainbow smelt once extended as far south as Delaware Bay (Scott and Crossman, 1973), but more recent information indicates that populations south of Massachusetts are extinct or undetectable (Fried and Schultz ${ }^{3}$; Enterline et al., 2012). For this study, anadromous rainbow smelt were sampled near the present southern extent of their range in marine waters and

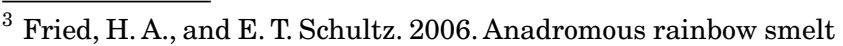
and tomcod in Connecticut: assessment of populations, conservation status, and need for restoration plan. Univ. Conn., Dep. Ecol. Evol. Biol., EEB Article 18, 262 p. [Available from website.]
} 


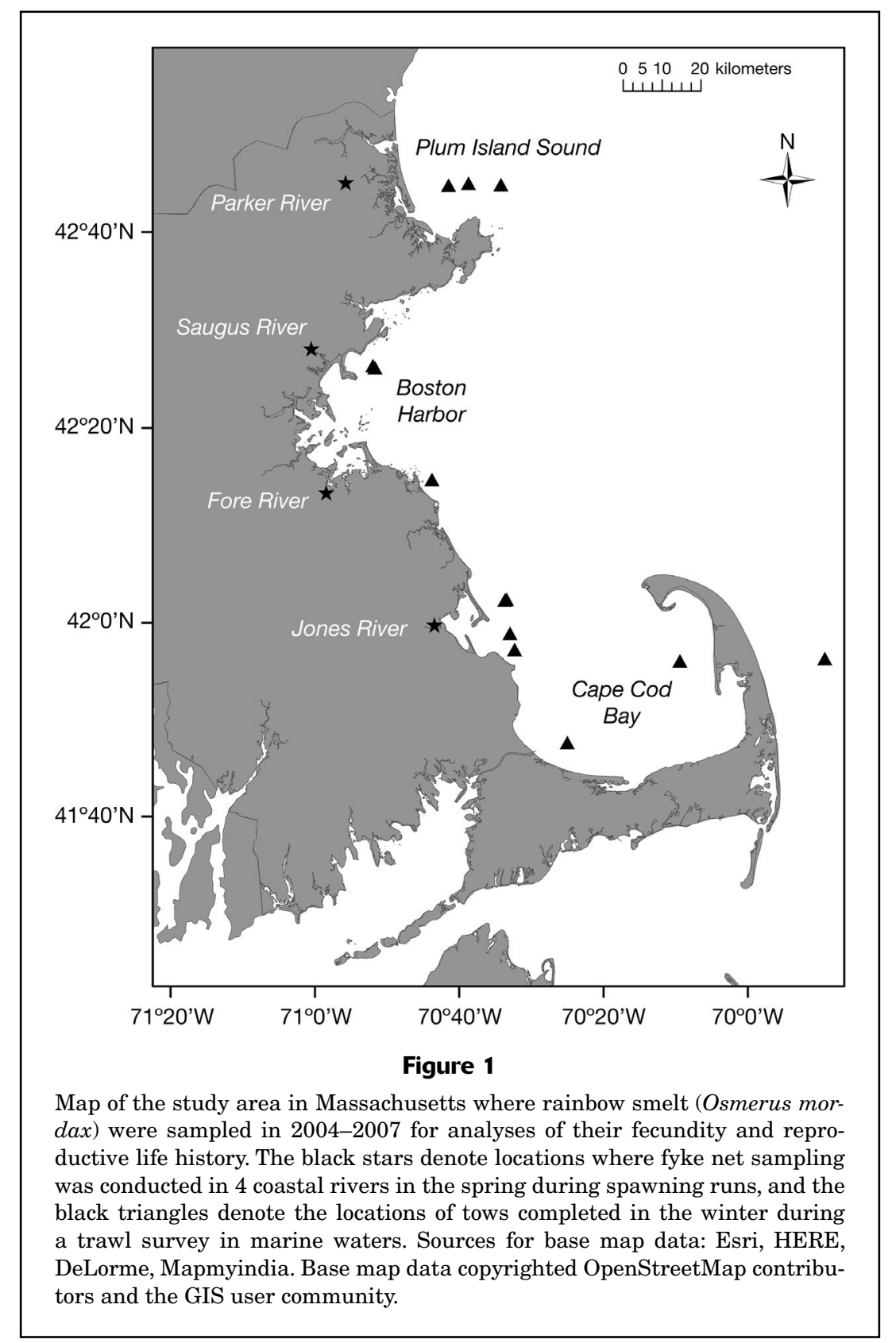

coastal rivers from Cape Cod Bay to Plum Island Sound, Massachusetts, in the western Gulf of Maine (Fig. 1).

\section{Reproductive analyses}

Fecundity Rainbow smelt were collected and frozen whole during a trawl survey for Atlantic cod (Gadus morhua) conducted by staff of the Massachusetts Division of Marine Fisheries aboard a commercial vessel in winter from 2004 through 2007, by using a standardized 2 -seam, high-rise bottom-trawl net with a 26.5 -m sweep, 25.6-m headrope, $11.43-\mathrm{cm}$ wing mesh, $7.62-\mathrm{cm}$ codend mesh, and 5.08-cm mesh liner (Hoffman et al. ${ }^{4,5}$ ). The meshes were diamond-shaped, and their measurements were taken when they were stretched. The target time for tows was $30 \mathrm{~min}$, and the functional headrope height was

\footnotetext{
${ }^{4}$ Hoffman, W. S., S. J. Correia, and D. E. Pierce. 2012. Results of an industry-based survey for Gulf of Maine cod, November 2003-May 2005. Mass. Div. Mar. Fish. Tech. Rep. TR-49, 37 p. [Available from website.]

${ }^{5}$ Hoffman, W. S., S. J. Correia, and D. E. Pierce. 2012. Results of an industry-based survey for Gulf of Maine cod, May 2006December 2007. Mass. Div. Mar. Fish. Tech. Rep. TR-50, 45 p. [Available from website.]
} 
approximately $4.5 \mathrm{~m}$. This winter trawl survey provided an opportunity to sample maturing rainbow smelt prior to their spawning migration into coastal rivers and, therefore, to avoid bias associated with analyzing fecundity of fish intercepted during spawning runs when partially spawned fish are present and oocytes can be extruded during handling.

In the laboratory, frozen rainbow smelt were thawed, excess water was removed with absorbent paper, and total weight (TW, to the nearest $0.01 \mathrm{~g}$ ), total length (TL, to the nearest $1 \mathrm{~mm}$ ), and sex were recorded. Subsamples of female rainbow smelt for fecundity analysis were selected with a target sample size of 10 fish for each length bin of $10 \mathrm{~mm}$. Scales were removed from the female subsamples between the lateral line and dorsal fin for age determination (Elzey et al. ${ }^{6}$ ). Female rainbow smelt have an asymmetrical ovarian pair with a left ovary larger than the right one. Ovaries were excised from females, excess tissue and water were removed, and ovarian weight (OW, to the nearest $0.01 \mathrm{~g}$ ) and maturation stage (Crim and Glebe, 1990) were recorded. Any remaining ovarian tissue and membrane that could not be removed was assumed to represent a negligible weight relative to the total ovary weight. Body weight (BW) was recorded as TW-OW.

Two subsamples of oocytes were removed for fecundity analysis from each paired ovary: one subsample anterior and one subsample posterior of the midpoint of each ovary. The sampling protocol targeted 500 oocytes/subsample to estimate egg density. Subsamples were placed on absorbent paper, weighed (to the nearest $0.01 \mathrm{~g}$ ), and fixed in $3 \%$ formalin in small jars; once in the jars, samples were shaken immediately to prevent oocytes from clumping together. Additionally, to confirm previous findings of synchrony in oocyte development (Chen, 1970; Clayton, 1976), 4 oocyte subsamples were collected from 4 rainbow smelt before samples were fixed to measure oocyte diameters. A finding that all oocytes developed at the same rate would support the use of determinate methods of fecundity estimation. Again, one subsample was collected anterior and one subsample posterior of the midpoint of each ovary. The diameter and maturity stage of 20 oocytes were recorded from each of these subsamples with an ocular micrometer (to the nearest $0.01 \mathrm{~mm}$ ). The Kruskal-Wallis rank sum test was used to determine if there were differences in oocyte diameter among the locations in the ovary where oocyte samples were removed.

Fixed subsamples of oocytes were processed for fecundity analysis by counting all oocytes with a compound microscope at $10 \times$ magnification. We calculated total fecundity, the number of mature oocytes prior to spawning, for an individual rainbow smelt as the product of the mean number of oocytes per gram for the 4 oocyte subsamples and the TW of the paired ovaries (Nielsen and Johnson, 1983).

\footnotetext{
${ }^{6}$ Elzey, S. P., K. J. Trull, and K. A. Rogers. 2015. Massachusetts Division of Marine Fisheries Age and Growth Laboratory: fish aging protocols. Mass. Div. Mar. Fish. Tech. Rep. TR-58, 43 p. [Available from website.]
}

Oocyte density (total estimated number of oocytes divided by $\mathrm{OW}$ ) and relative fecundity (total fecundity divided by $\mathrm{BW}$ in grams) also were calculated as reproductive indices to compare among age classes.

Total fecundity estimates for each individual were regressed against TL, TW, OW, and age to determine the relationships of fecundity to size and age of rainbow smelt. Regressions and the Shapiro-Wilk normality test were run on nominal data by using the MASS package, vers. 7.3-45 (Venables and Ripley, 2002), in the statistical software R, vers. 3.3.0 (R Core Team, 2016). The response variable and some predictor variables were not normally distributed, and all nominal regressions had patterns of variance inconsistency. As a result, both dependent variables and independent variables were log transformed to improve normality and the constancy of variance (Sokal and Rohlf, 1995). All analyses were performed in R, vers. 3.3.0. The level of statistical significance for all analyses was 0.05 .

Maturity Maturity and sex of marine samples of rainbow smelt were determined by macroscopic gonad examination. Immature rainbow smelt were readily identified because no development of gonadal tissue was visible; in contrast, the well-developed testis and ovaries of mature samples occupied a majority of the abdominal cavity space. Maturity ogives are important biological references used in stock assessments $\left(\mathrm{ICES}^{7}\right)$ and are critical for description of the reproductive potential of a short-lived, anadromous fish, such as the rainbow smelt. Logistic models are commonly used to determine the relation between body size and sexual maturity (Roa et al., 1999). In our study, we applied a generalized linear model (GLM) with binomial error structure and logit link function by using the MASS package in $\mathrm{R}$ to model maturity of rainbow smelt (ICES ${ }^{7}$ ). All marine samples of rainbow smelt were assigned a maturity status (mature or immature) that was used as the response variable in the model, and TL was used as the explanatory variable. The GLM assumes that all samples are independent and generates a multiyear estimate of the maturity ogive for sexes combined. The GLM estimates maturity at length when $50 \%$ of the population is mature $\left(L_{50}\right)$. A maturity ogive was not prepared for the samples collected with a fyke net during spawning runs because immature rainbow smelt were rare or absent at the 4 stations at coastal rivers where this fyke net sampling occurred.

Maturity and condition indices (Crim and Glebe, 1990) were generated to determine if maturation patterns were evident among age, size, and area subsets and to compare with earlier data sets (Chen, 1970; Clayton, 1976). Values of Fulton's condition factor, calculated as $K=$ (TW/ $\left.\mathrm{TL}^{3}\right) \times 100,000$, increase with increasing weight at a given length, an indication of better physical "condition" for a

\footnotetext{
${ }^{7}$ ICES (International Council for the Exploration of the Sea). 2008. Report of the workshop on maturity ogive estimation for stock assessment (WKMOG); Lisbon, Portugal, 3-6 June. ICES CM Documents 2008/ACOM:33, 72 p. [Available from website.]
} 
fish (Ricker, 1975). Differences in condition factor among sample locations and sex were tested with the KruskalWallis rank sum test and the Kruskal-Wallis multiple comparison test. The gonadosomatic index (GSI), calculated as $(\mathrm{OW} / \mathrm{BW}) \times 100$, and the fecundity index, calculated as total fecundity/ $\mathrm{TL}^{3}$, were determined for marine samples and the Fulton's condition factor was calculated for both the river and marine samples. Sex ratios of rainbow smelt sampled at all locations were tested for significant differences by using the chi-square test $(\alpha=0.05)$.

\section{Size and age analyses}

The Massachusetts Division of Marine Fisheries conducts annual fyke net sampling of rainbow smelt at spawning runs in coastal rivers to monitor abundance and size and age composition. Fyke nets were set in the Jones, Fore, Saugus, and Parker Rivers (Fig. 1) at mid-channel, intertidal locations downstream of spawning riffles to intercept spawning rainbow smelt 3 days a week over an 11-week spawning run (Chase et al., 2009; Enterline et al., 2012). Fyke nets were set in 2004-2007; however, the catch data for 2004 were not used because of changes in methods following that pilot season. The fyke nets have square wings that are $1.2 \times 1.2 \mathrm{~m}$ and lead to a square entrance, also $1.2 \times$ $1.2 \mathrm{~m}$, that connects to 7 hoops with a terminal codend after 2 throats (all mesh sizes were $7 \mathrm{~mm}$ ). At all locations, rainbow smelt were counted and measured for TL, and their sex was determined. Total length was measured for 100 male and female rainbow smelt from each haul, with all remaining rainbow smelt enumerated by sex. Spawning male rainbow smelt are readily identified by the presence of nuptial tubercles. At the Fore and Saugus Rivers, samples were collected randomly from each haul to additionally measure TW and to collect scales for aging. The subsamples for aging were collected with a weekly tally of 5 samples per $10-\mathrm{mm}$ bin per sex.

Length and weight correction Measurements of the samples collected with a fyke net were made when fish were fresh, but the marine samples were frozen prior to processing. To allow direct comparison of length and weight data for the 2 sets of collections, a sample of rainbow smelt caught with a fyke net in the Fore River were measured for length and weight before and after they were frozen, and changes in length and weight were compared with regression analysis.

Length analysis The TL of rainbow smelt collected at the 4 stations where fyke net sampling occurred and caught during the trawl survey were evaluated for differences among locations and sexes by using the Kruskal-Wallis rank sum test and the Kruskal-Wallis multiple comparison test. Given limitations of sample sizes, all samples from the trawl survey were pooled for the study period. Length and length-at-age analyses (only for samples from the Fore River) were conducted on pooled samples for the study period when sample sizes allowed meaningful comparisons. The interpretation of length data among sample locations must be made cautiously because of the within-season repeat-spawning behavior of males (Murawski and Cole, 1978) and changes in size and age of rainbow smelt that occur temporally during a spawning run (Marcotte and Trembley, 1948; McKenzie, 1964).

Age analysis Age keys were prepared for Fore River samples and for the data pooled for samples from the Fore and Saugus Rivers. Age keys combined sexes and annual data for the study period. The pooled age key was applied to length frequencies of samples from the Saugus, Jones, and Parker Rivers to estimate age composition for those rivers. The age compositions were applied to the Chapman-Robson age-based survival estimator, by using the Fishmethods package, vers. 1.10-4 (Nelson, 2017) in $\mathrm{R}$ to estimate annual survival $(S)$ and instantaneous total mortality $(Z)$ rates. Annual age data for each sampling location were combined for the study periods to smooth the effect of year-class variation and as a practical approach to allow a comparison of sparsely reported population demographics for anadromous rainbow smelt. The annual age proportions estimated for rainbow smelt from fyke net sampling were compared with historical data (Murawski and Cole, 1978; Lawton et al. ${ }^{8}$ ) by using the chi-square test $(\alpha=0.05)$.

Length-weight analysis Length-weight data from the trawl survey samples were compared with length-weight data from the fyke net samples to examine seasonal differences in condition of rainbow smelt, and as an alternative means to consider if the pooled samples of rainbow smelt from the trawl survey composed a representative sample for fecundity analysis. We used linear regression on natural log-transformed TL and TW data for rainbow smelt collected for fecundity analysis and fyke net monitoring. The homogeneity of slopes was tested by analysis of covariance to determine if length or weight differed significantly by location, sex, or age class $(P<0.05)$. Length was the independent variable, weight was the dependent variable, and location, sex, and age class were the group variables.

\section{Results}

\section{Reproductive analyses}

During the trawl survey in 2004-2007, 634 rainbow smelt were collected from 13 tows of the trawl between 11 January and 5 March (Fig. 1). Rainbow smelt were captured in nearshore, marine waters off Massachusetts at an average depth of $38 \mathrm{~m}$ (range: 19-89 m) with an

\footnotetext{
${ }^{8}$ Lawton, R., P. Brady, C. Sheehan, S. Correia, and M. Borgatti. 1990. Final report on spawning sea-run rainbow smelt (Osmerus mordax) in the Jones River and impact assessment of Pilgrim Station on the population, 1979-1981. Pilgrim Nuclear Power Station Mar. Environ. Monit. Program Rep. Ser. 4, 72 p. [Available from Mass. Div. Mar. Fish., 251 Causeway St., Ste. 400, Boston, MA 02114.]
} 


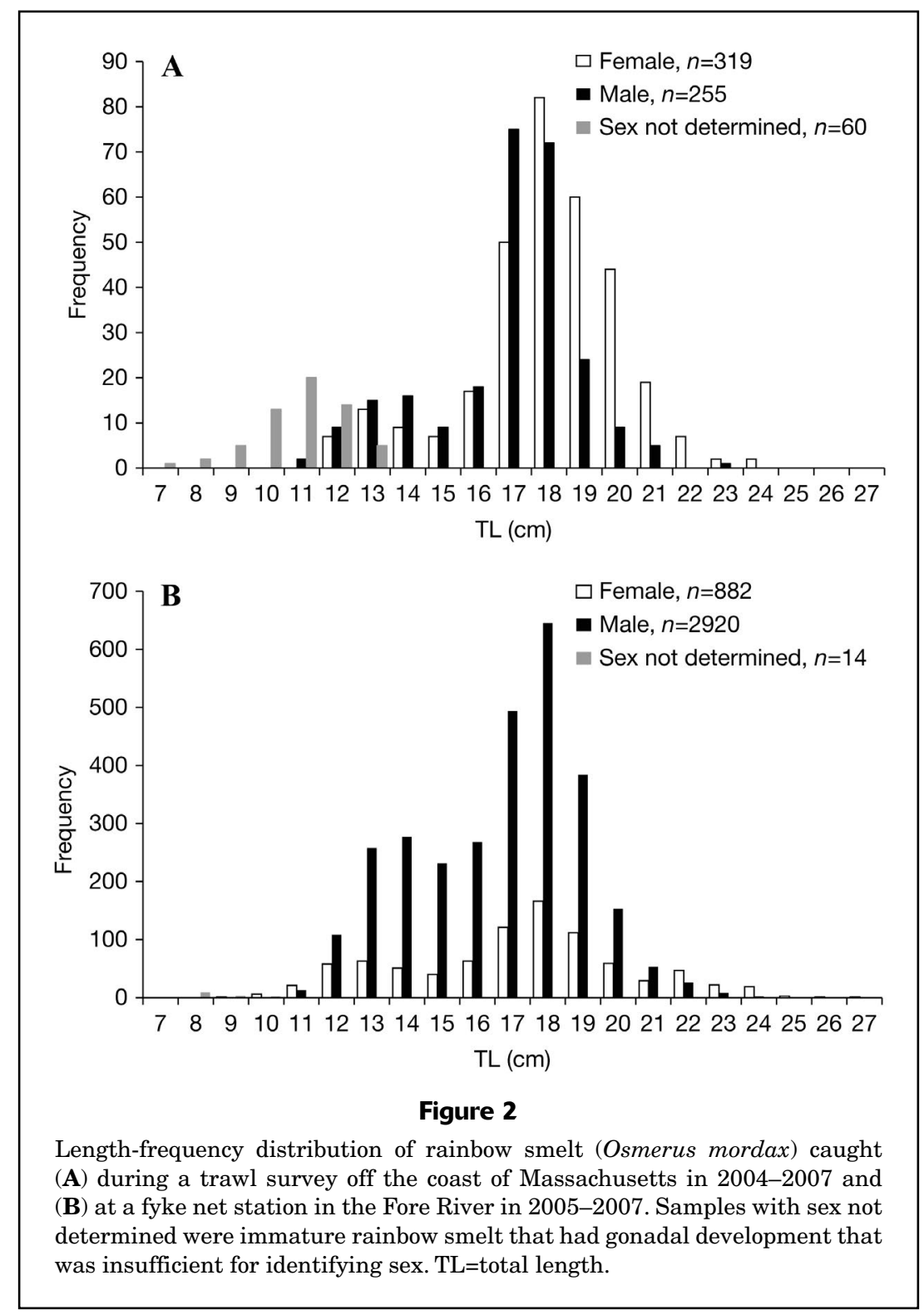

average water temperature of $3.6^{\circ} \mathrm{C}$ at the surface (range: $0.7-8.9^{\circ} \mathrm{C}$ ) and $3.5^{\circ} \mathrm{C}$ (range: $0.7-7.2^{\circ} \mathrm{C}$ ) on the bottom. The highest catch rates for rainbow smelt occurred in Cape Cod Bay and Massachusetts Bay at an average depth of $26 \mathrm{~m}$ (range: $19-30 \mathrm{~m}$ ). Of the total sample, 255 rainbow smelt were male (3 immature), 319 rainbow smelt were female ( 1 immature), and the sex could not be determined for 60 fish (all immature) (Fig. 2A). All samples used in fecundity analysis $(n=110)$ were aged (except 3 fish for which the scale samples had degraded). Sex, TL, and TW were recorded for all captured rainbow smelt, except for fish caught during 3 tows of the trawl in 2007, when females in unfilled TL bins for fecundity analysis were collected and all other rainbow smelt had their TL measured and sex determined.
Fecundity Mean total fecundity in rainbow smelt increased $270 \%$ from age 1 to age 2 and $170 \%$ from age 2 to age 3 (Table 2). The highest variability in fecundity was observed for age- 2 rainbow smelt (Fig. 3A) as a consequence of the wide range of size represented for this age (Fig. 2A). Mean and maximum total fecundity of age- 3 and age- 4 fish were nearly the same, and rainbow smelt of both ages had much higher minimum fecundity than fish in the younger age classes (Fig. 3A). In regression analysis, total fecundity of rainbow smelt increased significantly with each measure of size and age (Table 3). The best-fitting relationship was that of fecundity and TW, closely followed by that of fecundity and TL (Table 3, Fig. 4). Although the regression of fecundity versus age was significant, the occurrence of 


\section{Table 2}

Summary statistics for rainbow smelt (Osmerus mordax) sampled during a trawl survey in marine waters off Massachusetts in 2004-2007 and for analysis of their fecundity. Data provided are sample size ( $n$ ), mean length, measured in millimeters in total length (TL), mean total weight (TW), mean gonadosomatic index (GSI), mean ovarian weight (OW), mean egg density, relative fecundity, measured as the number of oocytes divided by body weight (BW), and fecundity, measured as the number of mature oocytes prior to spawning.

\begin{tabular}{|c|c|c|c|c|c|c|c|c|c|}
\hline Age & $n$ & $\begin{array}{c}\text { Mean } \\
\text { length } \\
(\mathrm{mm} \text { TL) }\end{array}$ & $\begin{array}{l}\text { Mean } \\
\text { TW (g) }\end{array}$ & $\begin{array}{c}\text { Mean } \\
\text { GSI }\end{array}$ & $\begin{array}{l}\text { Mean } \\
\text { OW (g) }\end{array}$ & $\begin{array}{c}\text { Mean egg } \\
\text { density (no. } \\
\text { oocytes/OW) }\end{array}$ & $\begin{array}{l}\text { Mean relative } \\
\text { fecundity (no. } \\
\text { oocytes/BW) }\end{array}$ & $\begin{array}{l}\text { Fecundity } \\
\text { (no. of } \\
\text { oocytes) }\end{array}$ & $\begin{array}{c}\text { Mean } \\
\text { fecundity } \\
\text { (no. of oocytes) }\end{array}$ \\
\hline 1 & 19 & 137 & 12.93 & 6.53 & 0.80 & 13,234 & 767 & 4880-14,102 & 9026 \\
\hline 2 & 76 & 184 & 36.79 & 11.23 & 3.96 & 8529 & 747 & $7885-50,001$ & 24,624 \\
\hline 3 & 8 & 215 & 65.45 & 15.10 & 8.65 & 6118 & 789 & $25,559-51,651$ & 42,957 \\
\hline 4 & 4 & 231 & 88.34 & 25.39 & 17.42 & 2652 & 633 & $36,721-47,328$ & 43,927 \\
\hline
\end{tabular}
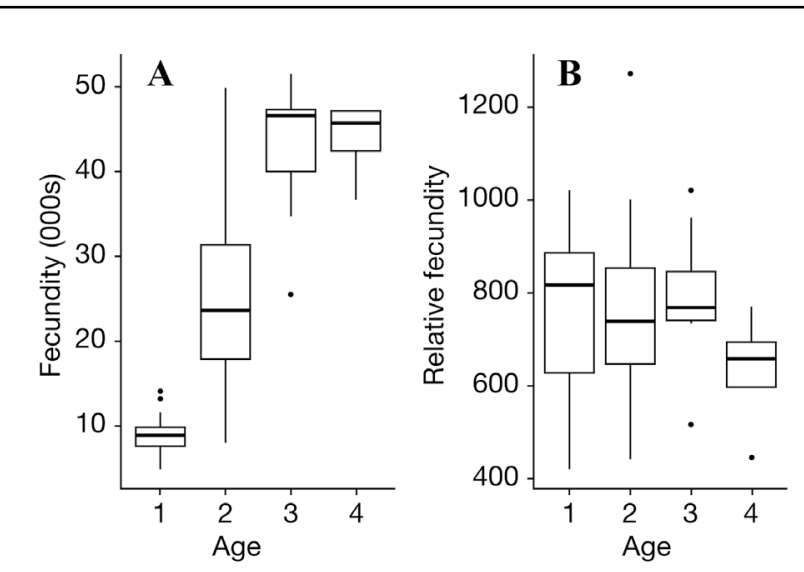

Figure 3

Boxplots (A) of total fecundity, measured as the number of mature oocytes prior to spawning, and (B) of relative fecundity, measured as the number of oocytes divided by body weight, by age class, for rainbow smelt (Osmerus mordax) sampled during a trawl survey in marine waters off Massachusetts in 2004-2007. The lower and upper hinges of the box plots correspond to the $25^{\text {th }}$ and $75^{\text {th }}$ percentiles. The whiskers extend from the hinge to the farthest value no more than 1.5 times the interquartile range (distance between the $25^{\text {th }}$ and $75^{\text {th }}$ percentiles). Data beyond the end of the whiskers, called outlying points, are plotted individually.

only 4 age classes and low sample sizes for age- 3 and age- 4 rainbow smelt resulted in the lowest coefficient of multiple determination $\left(R^{2}\right)$ among predictor variables (Table 3). Mean oocyte density (number of eggs per gram) declined sharply with age (Table 2). Mean oocyte density was 5 times higher in age- 1 rainbow smelt than in age-4 rainbow smelt. Overall, relative fecundity was similar among age classes (Fig. 3B) with declines in oocyte density with age compensated by increases in body and ovary size.
Maturity ogive A multiyear maturity ogive for both sexes combined was estimated from the sample of 634 rainbow smelt collected with a trawl in marine waters, with 64 immature fish included (Fig. 5). The GLM was significant for the intercept and TL $(P<0.001)$ and estimated $L_{50}$ at $126.2 \mathrm{~mm}$ TL. Maturity ogive estimates were not possible for the samples collected in coastal rivers with a fyke net during spawning runs because of the near absence of immature rainbow smelt. However, mean length of age-1 rainbow smelt (range: 140-147 mm TL) was greater at the locations of fyke net sampling than the $L_{50}$, indicating that not all age- 1 rainbow smelt are recruited to spawning runs (Table 4). Our data are not sufficient to produce annual ogives or separate ogives for each sex. A slight difference in maturity ogive between sexes may occur given the differences in mean length.

Oocyte diameter The diameters of oocytes from the ovaries of a subsample of 4 rainbow smelt were measured before samples were fixed in formalin to determine if oocyte diameter and maturity differed among locations in the ovary where oocytes were removed. There was no variation in oocyte appearance or stage among samples: all had dense, dark yellow yolk, consistent with maturing oocytes of later vitellogenic stages (Crim and Glebe, 1990). No significant differences were found among the 4 subsamples of rainbow smelt by using the Kruskal-Wallis rank sum test $\left(\chi^{2}=3.91,5.78,11.07\right.$, and 6.72 ; degrees of free$\operatorname{dom}(\mathrm{df})=6 ; P>0.05)$. No further oocyte diameter measurements were made given the confirmation of the reports by Chen (1970) and Clayton (1976) that oocyte maturity of rainbow smelt was evenly distributed along ovaries and the subsequent finding that fixing the remaining samples in $3 \%$ formalin reduced oocyte size and distorted shape.

\section{Size and age analyses}

Fyke net samples During spawning runs in the spring of 2005-2007, 13,428 rainbow smelt were caught with fyke nets at locations in 4 coastal rivers (Table 5). Rainbow smelt were caught routinely with relatively high frequency of occurrence in hauls at each location. The fyke 


\section{Table 3}

Regression coefficients from analysis of the relationships of fecundity and independent variables of size and age for rainbow smelt (Osmerus mordax) collected in marine waters off Massachusetts during 2004-2007. Variables were logtransformed for all regressions. Standard errors of the mean (SEs) are given for intercept and slope values. All values for the $F$-statistic are significant $(P<0.001)$. $R^{2}=$ coefficient of multiple determination; $S_{\mathrm{y} \cdot \mathrm{x}}^{2}=$ residual mean square.

\begin{tabular}{lcccccc}
\hline Variable & $n$ & $R^{2}$ & $S_{\mathrm{y} \cdot \mathrm{x}}^{2}$ & $F$ & Intercept (SE) & Slope (SE) \\
\hline Length & 110 & 0.891 & 0.040 & 884.9 & $-6.404(0.549)$ & $3.166(0.106)$ \\
Total weight & 110 & 0.899 & 0.037 & 961.1 & $6.765(0.104)$ & $0.927(0.030)$ \\
Ovarian weight & 110 & 0.739 & 0.096 & 305.7 & $9.411(0.042)$ & $0.518(0.030)$ \\
Age & 107 & 0.524 & 0.174 & 115.4 & $7.721(0.209)$ & $2.062(0.192)$
\end{tabular}
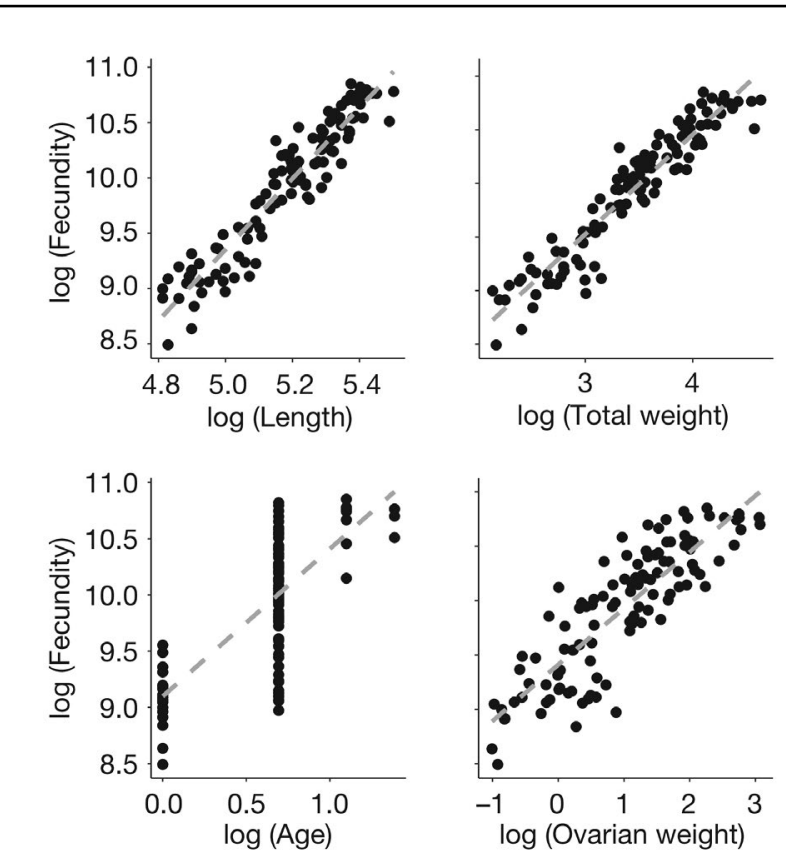

Figure 4

Regressions of the relationships between fecundity and the size and age of rainbow smelt (Osmerus mordax) sampled in marine waters off Massachusetts during a trawl survey in 2004-2007. See Table 2 for summary statistics from fecundity analysis and Table 3 for regression coefficients. The vertical clusters of points in the log (Age) graph represent ages 1-4 from left to right, respectively. The dashed lines indicate the fitted regression model values. Lengths are given as total lengths in millimeters, and weights are total weights given in grams.

net sampling at the location in the Fore River had the highest total catch, frequency of occurrence, and catch per unit of effort (number of rainbow smelt per overnight haul) among the 4 rivers. The results that follow include comparisons of size and age data for rainbow smelt caught during the trawl survey and fyke net sampling.
Length and weight correction A random sample of rainbow smelt was collected with the fyke net in the Fore River to measure length and weight when fish were fresh $(<12 \mathrm{~h}$ after collection) and again after they had been frozen for 3 months. Regressions were generated for both TL and TW. No differences were found in the regression slopes between sexes through analysis of covariance. Therefore, the relationship between data for fresh and frozen samples that was used to correct the TL of trawl samples was determined with this equation: $T L_{\text {Fresh }}=-1.88893+0.99075 T L_{\text {Frozen }}(n=59$, $\left.R^{2}=0.985, P<0.001\right)$. The following equation was used to determine the relationship between data for fresh and frozen samples that was used to correct the TW of trawl samples: $T W_{\text {Fresh }}=-0.07561+0.98369 T W_{\text {Frozen }} \quad\left(n=59, \quad R^{2}=0.996\right.$, $P<0.001)$. When applied to data for trawl-caught rainbow smelt, these corrections increased post-frozen length and weight measurements by approximately $2-4 \%$ and decreased Fulton's condition factor by approximately $4 \%$.

Length analysis Differences in TL among rainbow smelt from the 4 fyke net stations and from the trawl samples were evaluated for the study period by using the KruskalWallis rank sum test and the Kruskal-Wallis multiple comparison test. Several trends were revealed from the analysis of pooled length data (Fig. 6). At all locations, males were shorter than females. Also, males and females from the southernmost station in the Jones River were shorter than those from all other locations, and males from the northernmost station in the Parker River were significantly longer than those from all other locations. Among samples from the trawl survey, the Fore River, and the Saugus River, there were no differences in TL except for females from the Fore River and Saugus River. This finding supports the premise that it was suitable to pool data from the trawl samples for the study area and compare length and age distributions to data from samples collected in coastal rivers. This analysis and these length-frequency data raise no concerns over possible size selection that could have resulted from the use of trawl sampling gear (Fig. 2A).

Analysis of differences in TL among aged rainbow smelt found significant differences beyond those revealed from the previously mentioned analysis of pooled length data. 


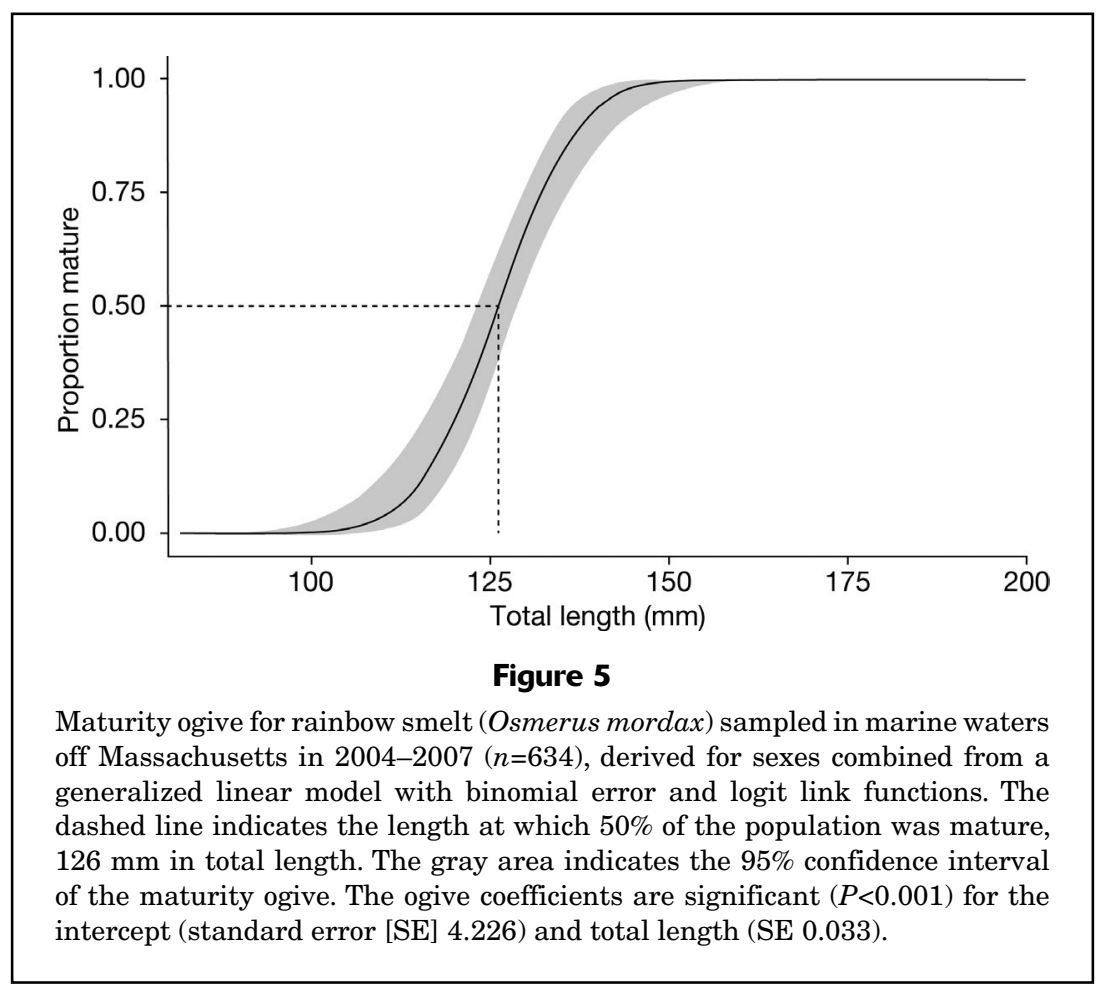

\begin{tabular}{|c|c|c|c|c|c|}
\hline \multicolumn{6}{|c|}{$\begin{array}{l}\text { Summary of total lengths (TLs) of rainbow smelt (Osmerus mordax) for which age was determined } \\
\text { in this study. Fish were sampled in Massachusetts in marine waters during a trawl survey in } \\
2004-2007 \text { and in the Fore and Saugus Rivers with fyke nets in 2005-2007. Significant differences } \\
\text { in TL among age and location groups were tested with the Kruskal-Wallis rank sum and multiple } \\
\text { comparison tests }(\alpha=0.05) \text {. Asterisks }(*) \text { indicate groups with significantly different TLs within each } \\
\text { age and sex category. }\end{array}$} \\
\hline Age & Sex & Sampling location or type & $(n)$ & Mean $(\mathrm{mm})$ & $\mathrm{SE}$ \\
\hline 1 & Male & $\begin{array}{l}\text { Trawl survey } \\
\text { Fore River } \\
\text { Saugus River }\end{array}$ & $\begin{array}{r}0 \\
174 \\
149\end{array}$ & $\begin{array}{l}140^{*} \\
147^{*}\end{array}$ & $\begin{array}{l}0.88 \\
0.98\end{array}$ \\
\hline 2 & Male & $\begin{array}{l}\text { Trawl survey } \\
\text { Fore River } \\
\text { Saugus River }\end{array}$ & $\begin{array}{r}0 \\
382 \\
144\end{array}$ & $\begin{array}{l}180^{*} \\
189^{*}\end{array}$ & $\begin{array}{l}0.61 \\
1.12\end{array}$ \\
\hline 1 & Female & $\begin{array}{l}\text { Trawl survey } \\
\text { Fore River } \\
\text { Saugus River }\end{array}$ & $\begin{array}{l}19 \\
77 \\
51\end{array}$ & $\begin{array}{l}137^{*} \\
142 \\
145^{*}\end{array}$ & $\begin{array}{l}2.46 \\
1.45 \\
1.46\end{array}$ \\
\hline 2 & Female & $\begin{array}{l}\text { Trawl survey } \\
\text { Fore River } \\
\text { Saugus River }\end{array}$ & $\begin{array}{r}75 \\
159 \\
39\end{array}$ & $\begin{array}{l}184 \\
191 \\
205^{*}\end{array}$ & $\begin{array}{l}2.61 \\
1.16 \\
2.16\end{array}$ \\
\hline
\end{tabular}

All fish from the Saugus River were larger at age 1 and age 2 than fish from the Fore River and the trawl survey, except for age- 1 female rainbow smelt from the Fore River (Table 4). Total lengths of age- 1 and age-2 females from the Fore River were not different from those of females from the trawl survey. Year-to-year TL comparisons were limited to the Fore River because of sample sizes. Differences were found among 3 comparisons of annual data for samples from the Fore River: males caught in 2005 and 2007 and females sampled in 2007 with females captured in both 2005 and 2006. These comparisons of length statistics may reflect changes in annual growth rates and cohort strength; however, these results can be confounded by pooling samples by year. 


\section{Table 5}

Summary of fyke net sampling of rainbow smelt (Osmerus mordax) in 4 coastal rivers of Massachusetts during 2005-2007. Data provided are drainage area of each river; mean monthly discharge of each river, given as cubic meters per second averaged for the month of April over the period 2005-2007; sample size ( $n$ ); mean catch per unit of effort (overnight haul) (CPUE); and frequency of occurrence (FOC) in hauls of fyke nets.

\begin{tabular}{|c|c|c|c|c|c|c|}
\hline River & Drainage area $\left(\mathrm{km}^{2}\right)$ & Discharge $\left(\mathrm{m}^{3} / \mathrm{s}\right)$ & Year & $n$ & CPUE & FOC \\
\hline \multirow[t]{3}{*}{ Parker } & 156.4 & 2.8 & 2005 & 924 & 35.5 & 0.53 \\
\hline & & & 2006 & 123 & 4.2 & 0.66 \\
\hline & & & 2007 & 563 & 24.5 & 0.61 \\
\hline \multirow[t]{3}{*}{ Saugus } & 124.8 & 1.9 & 2005 & 141 & 4.4 & 0.56 \\
\hline & & & 2006 & 1458 & 48.6 & 0.87 \\
\hline & & & 2007 & 2433 & 76.0 & 0.61 \\
\hline \multirow[t]{3}{*}{ Fore } & 93.5 & 2.4 & 2005 & 2131 & 71.0 & 0.90 \\
\hline & & & 2006 & 1014 & 35.0 & 0.90 \\
\hline & & & 2007 & 3435 & 107.3 & 0.81 \\
\hline \multirow[t]{3}{*}{ Jones } & 76.7 & 2.1 & 2005 & 489 & 15.3 & 0.72 \\
\hline & & & 2006 & 614 & 21.3 & 0.93 \\
\hline & & & 2007 & 103 & 3.2 & 0.50 \\
\hline
\end{tabular}

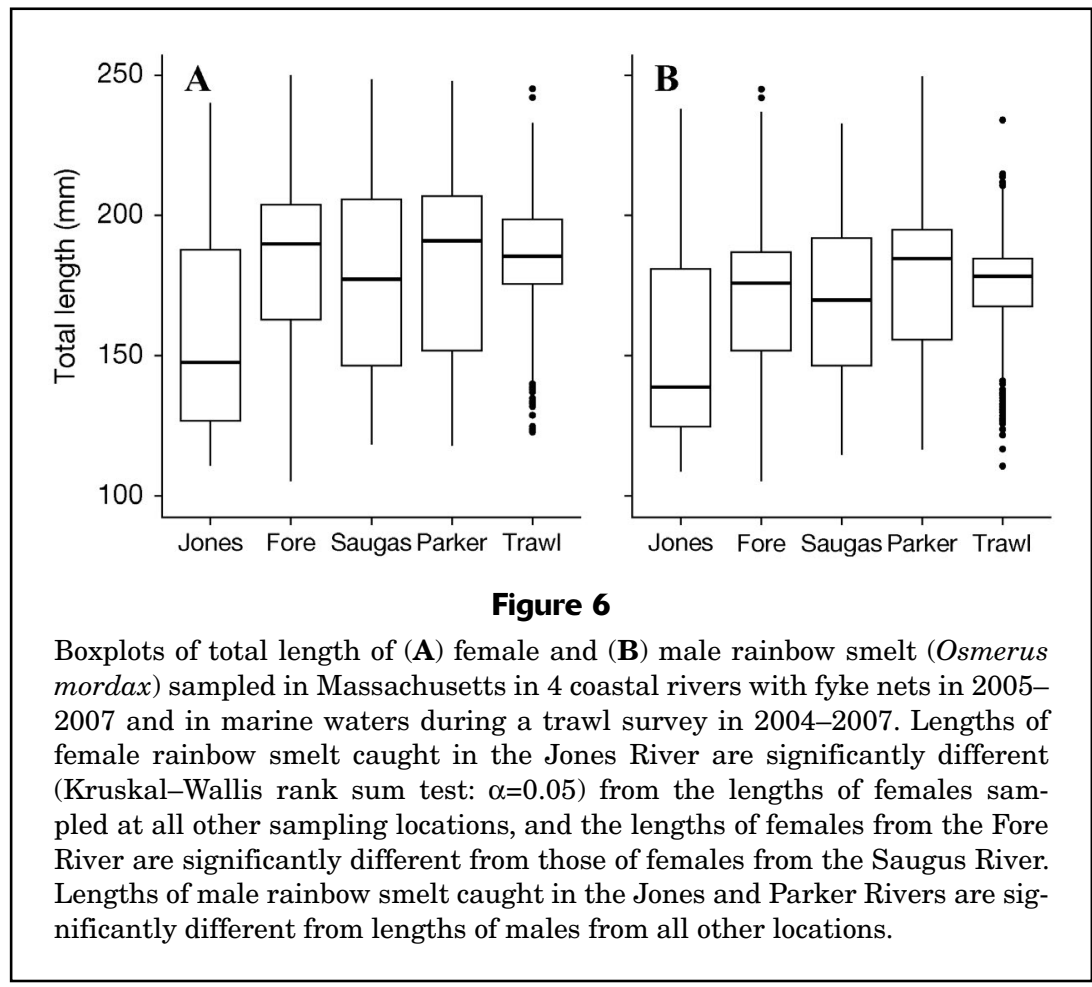

Age analysis For samples caught both with a trawl net in marine waters and with a fyke net in coastal rivers, age 2 was the most abundant age class of rainbow smelt, and few rainbow smelt older than age 2 were present (Table 2 , Fig. 7). Age-1 rainbow smelt composed the next most common age class with evidence of fluctuations in annual recruitment. Despite our collection of a relatively large sample of rainbow smelt from the trawl survey $(n=634)$, this sample produced only 12 age- 3 and 4 age- 4 female rainbow smelt for fecundity analysis.

The age data for rainbow smelt from fyke net sampling were compared with data from 2 previous studies that aged rainbow smelt during spawning runs in the Parker and Jones Rivers (Murawski and Cole, 1978; Lawton et al. $^{8}$ ). A lower proportion of age-1 rainbow smelt were caught from the Jones and Parker Rivers in 4 of the 


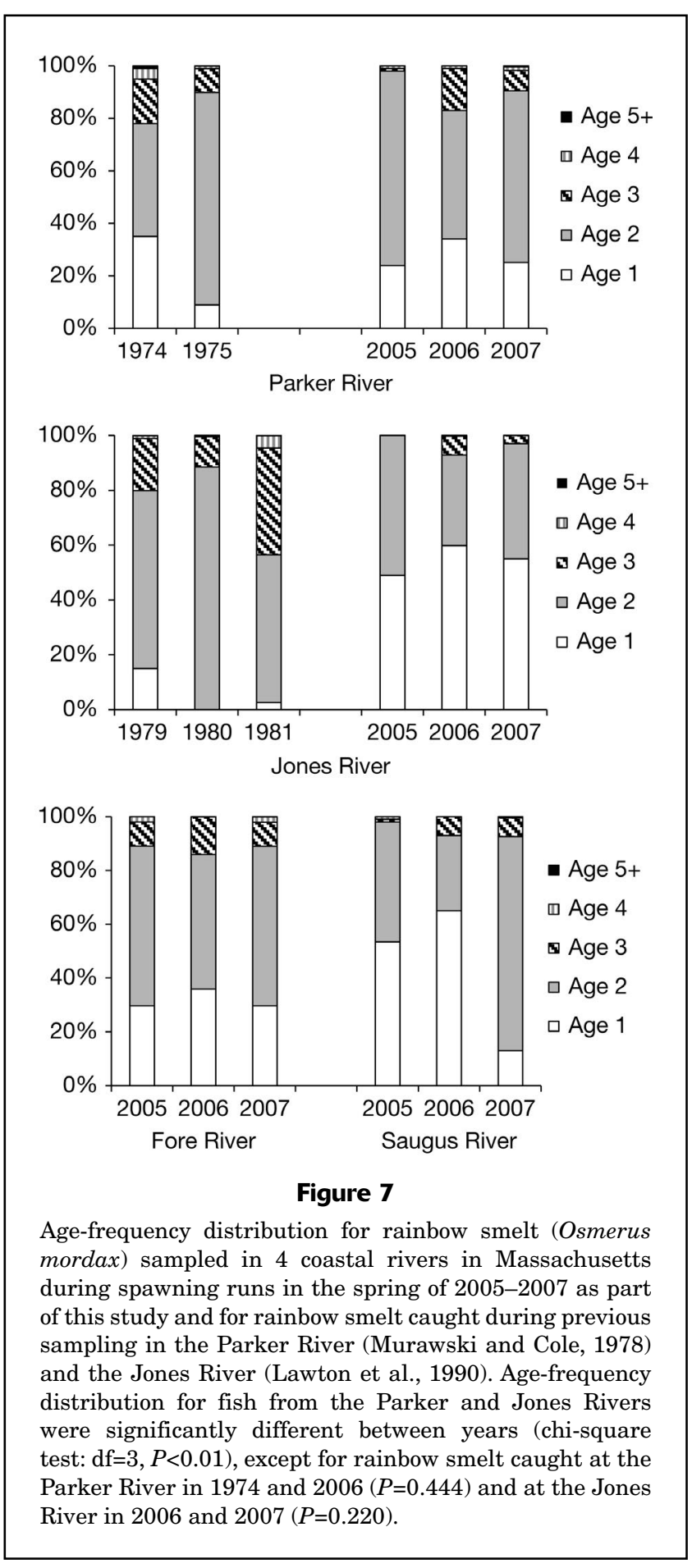

5 annual samples in those studies than in each of the annual samples of our study (Fig. 7). The change is most pronounced in the Jones River, with an average annual frequency of $6 \%$ for age-1 rainbow smelt from 1979 through 1981 and 55\% from 2005 through 2007. Additional evidence of changes in age structure was found in the Jones River: the average annual frequency of age-3 fish decreased from $23 \%$ during $1979-1981$ to $3 \%$ during 2005-2007. These comparisons indicate a shift in age composition with a larger role for age-1 rainbow smelt in spawning runs.

The Chapman-Robson age-based survival estimator used in this study produced lower estimates of $S$ and higher values of $Z$ for rainbow smelt caught in the Jones and Parker Rivers than the estimates reported for the previous studies (Table 6). For all data sets of ages of rainbow smelt, $Z$ estimates were calculated by using the Chapman-Robson estimator with years and sexes combined. Samples from the Fore River, with the highest representation of rainbow smelt older than age 2 , had $S$ and $Z$ estimates closest to those of samples from the Parker and Jones Rivers in the earlier studies. Rainbow smelt from the Jones and Saugus Rivers had lower $S$ and higher $Z$ than samples from the Fore River and those examined in Murawski and Cole (1978) and Lawton et al. ${ }^{8}$, as well as in another earlier study for which age data were reported for rainbow smelt in the Miramichi River in New Brunswick, Canada (McKenzie, 1964).

Length-weight analysis Length and weight data for the rainbow smelt from fyke net sampling and the trawl survey were evaluated as a measure of fish condition and to determine if differences occurred among sampling locations (Table 7). All regressions of the relationship of length and weight exhibited allometric growth with minor apparent differences between the trawl samples collected in winter and fyke net samples collected in spring. For all comparisons, the regression slopes were larger for females than males. There were no differences in the same-sex regression slopes for rainbow smelt collected at the Fore and Saugus Rivers. However, for both sexes, the regression slopes for the fyke net samples collected in coastal rivers did differ from those for the trawl samples collected in marine waters. Female rainbow smelt were significantly heavier at length than males for all locations, and the marine samples were heavier at length than the river samples.

Sex ratio The trawl samples collected in winter included significantly more females than males (1.3:1.0 female-tomale ratio; chi-square test: $\chi^{2}=7.13, \mathrm{df}=1, P=0.008$ ), and the fyke net samples collected in spring included significantly more males than females (male-to-female ratios: Jones River, 1.8:1.0; Fore River, 3.3:1.0; Saugus River, 10.6:1.0; and Parker River, 5.7:1.0; chi-square test: $\chi^{2}=88,1092$, 1653, and 533, respectively, $\mathrm{df}=1, P<0.001)$. The higher number of males captured with the fyke net is a sampling bias that resulted from males spawning more frequently than females (Marcotte and Tremblay, 1964; McKenzie, 1964; Murawski et al., 1980). It is possible that the unbalanced sex ratio found in trawl samples is biased by a higher proportion of males than females for the 60 immature rainbow smelt that were excluded from the sex ratio estimate.

Condition indices Fulton's condition factor for the trawl samples from marine waters and for the fyke net samples from the Fore and Saugus Rivers ranged between 


\section{Table 6}

Estimates of survival $(S)$ and total instantaneous mortality $(Z)$ of rainbow smelt (Osmerus mordax) sampled in 4 coastal rivers of Massachusetts in 2005-2007 for this study and of rainbow smelt in previous studies. For all data sets, annual age keys were applied to length-frequency data, and age data from sample years and sexes were combined and applied to the Chapman-Robson age-based survival estimator with age-1 fish excluded.

\begin{tabular}{lclrrr}
\hline $\begin{array}{l}\text { Sampling } \\
\text { location or type }\end{array}$ & Years & \multicolumn{1}{c}{ Source } & $n$ & $S$ (SE) & $Z$ (SE) \\
\hline Fore River & $2005-2007$ & This study & 2762 & $0.12(0.004)$ & $2.11(0.03)$ \\
Saugus River & $2005-2007$ & This study & 1427 & $0.11(0.008)$ & $2.23(0.07)$ \\
Jones River & $2005-2007$ & This study & 526 & $0.08(0.011)$ & $2.52(0.14)$ \\
Parker River & $2005-2007$ & This study & 803 & $0.10(0.010)$ & $2.27(0.10)$ \\
Trawl survey & $2004-2007$ & This study & 517 & $0.10(0.013)$ & $2.28(0.12)$ \\
Miramichi River & $1949-1953$ & McKenzie, 1964 & 18,072 & $0.28(0.003)$ & $1.27(0.01)$ \\
Parker River & $1974-1975$ & Murawski and Cole, 1978 & 1595 & $0.16(0.008)$ & $1.82(0.05)$ \\
Jones River & $1979-1981$ & Lawton et al., 1990 & 34,268 & $0.18(0.002)$ & $1.71(0.01)$ \\
& & & & &
\end{tabular}

\begin{tabular}{|c|c|c|c|c|c|c|c|}
\hline \multicolumn{8}{|c|}{$\begin{array}{l}\text { Regression coefficients from length-weight analysis (log-transformed total length and total weight data) } \\
\text { for rainbow smelt (Osmerus mordax) sampled in Massachusetts in } 2004-2007 \text { in marine waters during a } \\
\text { trawl survey and at the Fore River and Saugus River with fyke nets. } \mathrm{SE}=\text { standard error; } R^{2}=\text { coefficient } \\
\text { of multiple determination; I=immature rainbow smelt with undetermined sex. }\end{array}$} \\
\hline $\begin{array}{l}\text { Sampling location } \\
\text { or type }\end{array}$ & Sex & Age & $n$ & Intercept $(a)$ & Slope (b) & Slope SE & $R^{2}$ \\
\hline \multirow{2}{*}{$\begin{array}{l}\text { Fore and Saugus } \\
\text { Rivers combined }\end{array}$} & $\mathrm{F}$ & All & 353 & -13.11 & 3.20 & 0.03 & 0.96 \\
\hline & M & All & 899 & -12.88 & 3.14 & 0.02 & 0.97 \\
\hline \multirow[t]{5}{*}{ Fore River } & $\mathrm{F}$ & All & 285 & -13.12 & 3.21 & 0.04 & 0.96 \\
\hline & $\mathrm{M}$ & All & 597 & -12.81 & 3.13 & 0.02 & 0.97 \\
\hline & $\mathrm{F}$ & 1 & 76 & -11.28 & 2.83 & 0.13 & 0.87 \\
\hline & $\mathrm{F}$ & 2 & 159 & -12.55 & 3.10 & 0.12 & 0.81 \\
\hline & $\mathrm{F}$ & 3 & 43 & -13.97 & 3.37 & 0.18 & 0.89 \\
\hline \multirow[t]{4}{*}{ Saugus River } & $\mathrm{F}$ & All & 68 & -13.08 & 3.19 & 0.08 & 0.96 \\
\hline & M & All & 302 & -12.96 & 3.15 & 0.03 & 0.97 \\
\hline & $\mathrm{F}$ & 1 & 28 & -15.30 & 3.63 & 0.25 & 0.89 \\
\hline & $\mathrm{F}$ & 2 & 39 & -10.16 & 2.64 & 0.25 & 0.75 \\
\hline \multirow[t]{4}{*}{ Trawl survey } & $\mathrm{F}$ & All & 277 & -14.23 & 3.41 & 0.04 & 0.96 \\
\hline & M & All & 215 & -14.59 & 3.47 & 0.05 & 0.96 \\
\hline & I & All & 59 & -12.76 & 3.09 & 0.14 & 0.89 \\
\hline & $\mathrm{F}$ & 2 & 76 & -13.48 & 3.26 & 0.10 & 0.94 \\
\hline
\end{tabular}

0.5 and 0.6 , and values were similar to those estimated by Chen (1970), except immature rainbow smelt from the trawl survey had an average factor $<0.5$. Females had higher values than males for each sampling location in Kruskal-Wallis rank sum tests: $\chi^{2}=170.41$ (Fore River), $\chi^{2}=38.57$ (Saugus River), $\chi^{2}=34.40$ (marine waters), $\mathrm{df}=1$, $P<0.001$. Kruskal-Wallis multiple comparison tests found the condition factor for males from the Saugus River to be lower than that for males from both the Fore River and marine waters, but among females, only rainbow smelt from the Fore River and trawl survey had different values (the factor for samples from the Fore River was higher). Fulton's condition factor for age-2 females differed for all locations (Kruskal-Wallis rank sum test: $\chi^{2}=17.71$, $\mathrm{df}=2$, 
$P<0.001)$. The GSI values ranged from $3.5 \%$ to $38.1 \%$ and increased with length and age (Table 2).

\section{Discussion}

The comparison of rainbow smelt caught during winter in coastal waters off Massachusetts to rainbow smelt caught during spring spawning runs in coastal rivers contributes information about sparsely described aspects of the reproductive life history of anadromous rainbow smelt. Data from this comparison provide quantitative relationships of fecundity with size and age, a maturity ogive, the first ogive available for anadromous rainbow smelt, and biological references necessary to investigate influences on recruitment of rainbow smelt. Age and length data indicate that the role of age- 1 rainbow smelt in spawning populations may be increasing. During the study period, the proportion of age- 1 rainbow smelt in spawning runs was higher than proportions previously found in Massachusetts (Murawski and Cole, 1978; Lawton et al. ${ }^{8}$ ), and differences in the size of age- 1 rainbow smelt and their proportion of the run age composition were observed between proximate spawning runs. The point of increasing participation of age- 1 rainbow smelt in spawning runs is supported by our data; however, future investigations should consider that the collection methods were not identical between studies, raw length and age data were not available for samples in the other studies, and age composition data in all studies were derived from pooled age keys.

The cause of differences in life history characteristics among populations of rainbow smelt is not well described. Our findings of differences in length and age imply that maturation and growth rates vary over a modest geographical range. Kovach et al. (2013) conducted an analysis of genetic population structure for anadromous rainbow smelt from the Gulf of Maine, including samples from the 4 fyke net stations in Massachusetts, and found differences within this small geographic range but no river-level genetic variation. The populations of the Fore River and Saugus River were most similar genetically (and were also examined as a single Boston Harbor group). The populations of the Parker River and Jones River were related to the Boston Harbor group, but a majority of their genetic distinctiveness was associated with other populations north of the Parker River and south of the Jones River.

\section{Fecundity and maturation}

The small sample sizes of previous studies of fecundity in rainbow smelt limited the quantitative analyses of fecundity data and the interpretation of life history relevance. The number of samples collected from the trawl survey and used in fecundity analysis in our study $(n=110)$ more than doubled that of the largest previous study of anadromous rainbow smelt ( $n=48$; Chen, 1970), and analyses with those samples included fecundity regression relationships with 4 size and age predictor variables. Our collection of late-winter, marine rainbow smelt avoided biases associated with sampling during active spawning runs. The sample size of 110 was reached by pooling trawl tows and years, and pooling data does not allow inferences on annual or geographic differences. The general similarities in length distributions, length-weight relationships, and age structure among the sample locations indicate that pooling samples from the trawl survey over the study range (approximately $120 \mathrm{~km}$ ) was suitable for regression analysis. A similar conclusion can be made on the pooling of age samples by year and sex and the application of age keys to sample rivers where rainbow smelt were not aged. Our analysis would be improved with the ability to consider annual differences in age composition by river and sex. However, the suspected influences of differences in annual growth rates and cohort strength on changes in mean length do not appear to translate to large changes in length-at-age data and age modes for this fast growing, short-lived species.

Our finding of increasing total fecundity and generally stable relative fecundity with age is interesting because of the implication of the higher reproductive potential of the uncommon older rainbow smelt due to higher fecundity and large oocyte size (Hixon et al., 2014). However, neither our study nor past reproductive studies of rainbow smelt have quantitatively addressed this point. Further investigation is needed on the role of oocyte size and fecundity in anadromous smelt reproductive potential.

The 2 previous studies with higher numbers of samples for fecundity analysis were focused on landlocked populations of rainbow smelt ( $n=172$, Chen, $1970 ; n=208$, Luey and Adelman, 1984). Chen (1970) found that fecundity for 3 landlocked populations and 1 anadromous population of rainbow smelt was significantly related to fork length, BW, OW, and age. His estimates of relative fecundity for the 4 stocks indicate that the anadromous stock was the most productive and had the highest mean Fulton's condition factor for both sexes. Luey and Adelman (1984) found significant differences in growth, fecundity-length relationship, and length distribution among 3 regions in western Lake Superior over a range of 220 $\mathrm{km}$; yet the differences were slight. They suspected that these population differences were related to selective pressures (environmental and predatory) from the relatively recent introduction of rainbow smelt to the Great Lakes (Luey and Adelman, 1984). They also found few significant differences in length frequency among gear types, years, and sampling locations but consistent differences in length distribution between males and females (Luey and Adelman, 1984).

A comparison of the maturity ogive derived from marine samples to the length-at-age data from river samples indicates that not all age-1 rainbow smelt are recruited to annual spawning runs. Our study also provides evidence of a higher proportion of age- 1 rainbow smelt in the spawning runs than has been found in previous studies. The actual extent of changes in the maturity 
schedule of anadromous rainbow smelt cannot be determined because of the lack of previous ogive estimates, sampling differences, and limited historical information on cohort dynamics and raw length data. Our work highlights important data gaps, especially the lack of understanding of the environmental and phenotypic triggers on maturity of rainbow smelt and of the underlying influences that caused the increase of age-1 rainbow smelt in spawning runs.

\section{Eggs per recruit}

The estimates of $Z$ and fecundity at age generated in this study were applied to an eggs-per-recruit (EPR) analysis that used the Fishmethods package in $\mathrm{R}$ and compared inputs from previous studies of rainbow smelt in the Parker River (Murawski and Cole, 1978), Jones River (Lawton et al. ${ }^{8}$ ), and Miramichi River (McKenzie, 1964). The purpose of the EPR analysis was to determine how lifetime fecundity responds to changes in fishing mortality $(F)$. We introduce the EPR analysis here, in the "Discussion" section, because of its dependency on historical references for model input parameters and exploratory approach. The model assumes that fecundity has not changed over time and requires assigned values for $F$ and natural mortality $(M)$; however, no empirical measurements exist for rainbow smelt in our study area. Murawski and Cole (1978) used McKenzie's (1964) age data for rainbow smelt from the Miramichi River to derive $Z$ (1.043) and tagging data to derive $F(0.062)$ and used the equation $Z=M+F$ to estimate $M$ as 0.981 ; then they applied $M$ to derive an $F$ of 0.268 for the population of rainbow smelt in the Parker River during 1974-1975. These values were used in our study as starting points for a sensitivity analysis on assumed levels of $M$ and $F$ given the estimates of $Z$.

The most influential inputs for the EPR model are $M$ and the proportion of fish mature at each age (PMAT). The only value available for the proportion of mature age-1 anadromous rainbow smelt is the 0.6 derived from the trawl survey data used in this study. The first run of the EPR model was made with PMAT fixed at 0.6 for all data sets except the data set from the study of rainbow smelt from the Miramichi River where slower growth resulted in no age-1 rainbow smelt participating in the spawning run. The results shown in Figure 8A indicate that samples from the Parker and Jones Rivers in the 1970s and 1980s had the highest EPR despite having higher $Z$ than those from the Miramichi River. The Miramichi River sample had the strongest presence of older rainbow smelt; however, with no age-1 rainbow smelt in the spawning run at that location, lifetime EPR was lower. Results of the EPR analysis indicate that the rainbow smelt populations in rivers in our study had relatively low and stable EPR and that reducing $F$ caused little improvement to EPR because $Z$ was dominated by $M$. The model estimated that EPR for rainbow smelt in the Jones River declined 38\% from that reported in Lawton et al. ${ }^{8}$ and that EPR for those in the Parker River declined
$24 \%$ from that reported in Murawski and Cole (1978) (at $F=0.200$ on the $x$-axis, Fig. $8 \mathrm{~A}$ ).

In the interest of investigating the role of age- 1 maturity, PMAT was reduced to 0.3 for the data sets based on samples from the Parker and Jones Rivers for a second run of the model. The decline in EPR from the model run with a PMAT of 0.6 to the model run with a PMAT of 0.3 for hypothetical spawning runs reflects the importance of age- 1 participation in the spawning runs sampled for this study: with PMAT reduction, the EPR for samples from the Jones River declined $32 \%$ and the EPR for samples from the Parker River declined $29 \%$ (at $F=0.200$ on the $\mathrm{x}$-axis, Fig. $8 \mathrm{~B}$ ). The third run of the EPR model was used to analyze the potential for reduced $F$ in samples collected during spawning runs for this study (Fig. 8C). For the first run of the EPR model, $F$ was set at 0.268 , the Murawski and Cole (1978) estimate for rainbow smelt from the Parker River, for all samples of spawning runs except those from the Miramichi River for which an $F$ estimate of 0.062 was available. However, the fishery for rainbow smelt in the 1970s occurred during winter from ice shacks set in the intertidal Parker River. That ice-shack fishery is essentially gone because it is uncommon in recent winters for estuary ice to be thick enough to safely support shack fishing. Therefore, the third EPR analysis set $F$ at 0.000 , with $Z$ equal to $M$ (Fig. 8C). Under this scenario of high $M$, the decline in EPR estimated in our study from the EPR reported for earlier studies was $44 \%$ for samples from the Jones River and $33 \%$ for samples from the Parker River (at $F=0.200$ on the x-axis, Fig. $8 C$ ). Changes in growth and maturity are possible influences that caused the proportion of age-1 rainbow smelt found in spawning runs sampled in our study to increase. However, this influence cannot be separated from cohort dynamics without further studies.

Evidence from our study and previous studies (Murawski and Cole, 1978; O’Malley et al., 2017) supports the premise that age- 1 anadromous rainbow smelt are partially recruited to spring spawning runs. Further, our data indicate that the proportion of age-1 rainbow smelt in spawning runs in the study area has increased from the level observed several decades ago and that the presence of rainbow smelt older than age 2 has declined. The decline in the proportion of older rainbow smelt in the spawning run is the primary influence that results in higher $Z$ estimates in this study. The higher proportion of age- 1 rainbow smelt does not directly affect $Z$ estimates because this cohort is not fully recruited and excluded from survival estimates. It has been noted that more males than females are precocious at age 1 in spawning runs of anadromous rainbow smelt (Murawski and Cole, 1978; Sutter, 1980). In this study, a higher proportion of males than females was found for mature age- 1 rainbow smelt at each river sampled with a fyke net, at ratios similar to the sex ratios for all ages combined from fyke net sampling; however, the bias created by a higher rate of repeat spawning in males limits the quantification of the true sex ratio. 


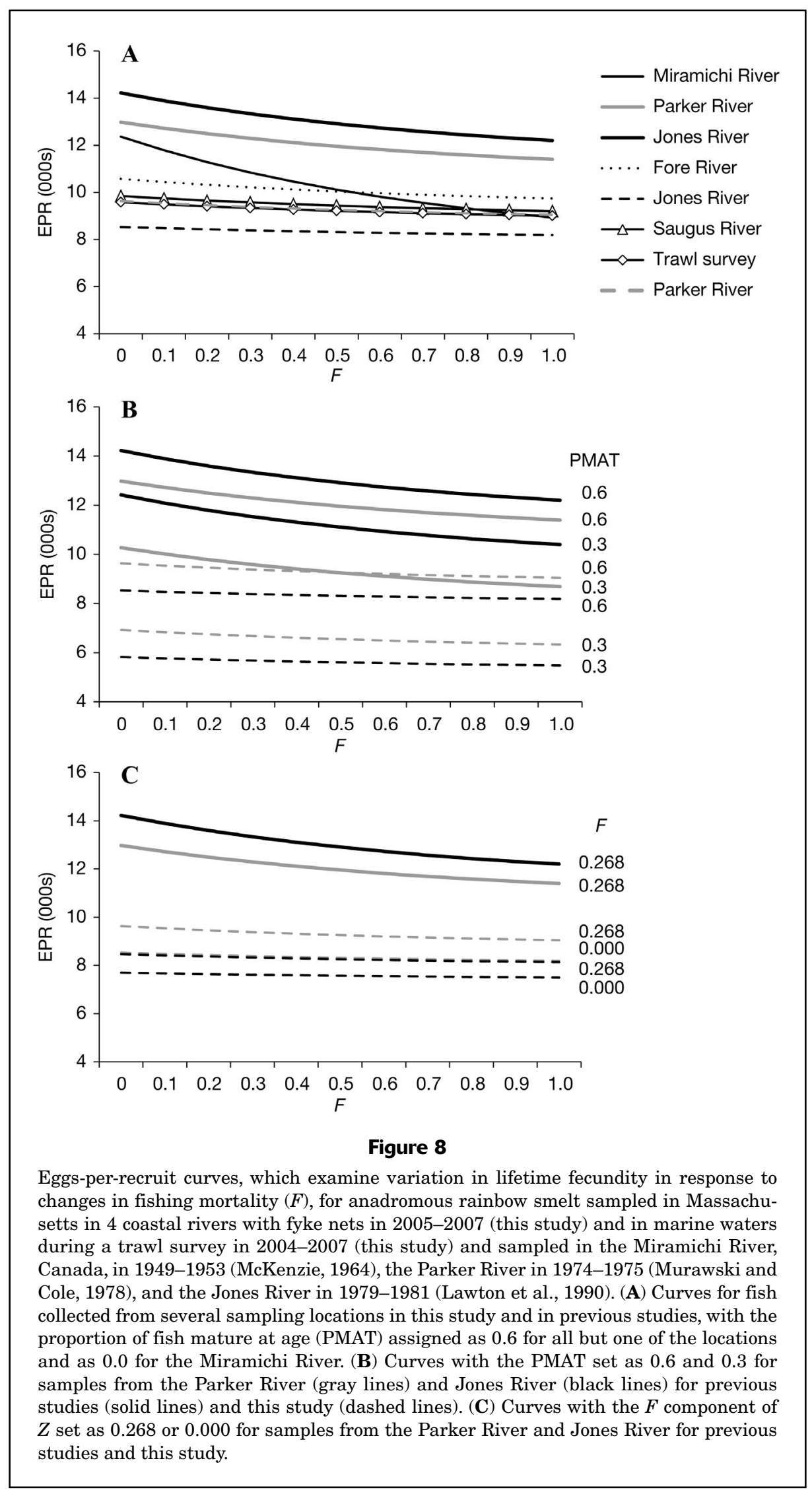




\section{Implications for populations of rainbow smelt}

A synopsis of information on stocks of rainbow smelt in the Gulf of Maine led to the conclusion that sharp declines have occurred in fisheries for and abundance of rainbow smelt in recent decades (Enterline et al., 2012). In Massachusetts, participation in rainbow smelt fisheries has declined to very low levels, and fisheries have ceased in most estuarine rivers where winter ice is no longer sufficient to support fishing. However, empirical measures of changes in population data related to this declining trend are absent. The fecundity data presented here indicate that reproductive potential has been lost with the decline in the proportion of rainbow smelt in spawning runs that are age 3 or older. This change is most pronounced in the spawning runs in the Jones River, where our data indicate that large increases in age-1 rainbow smelt and decreases in rainbow smelt age 3 or older have occurred. The results of analysis indicate declines of $20-40 \%$ in EPR from previous studies to this study for populations sampled in the Jones and Parker Rivers, and these estimates are most influenced by changes in $Z$, which does not include partially recruited age- 1 rainbow smelt. Given these age structure changes and that rainbow smelt age 3 or older are nearly 5 times as fecund as age- 1 rainbow smelt, spawning runs today may be recruitment limited. Despite this implication, the high proportion of age-1 rainbow smelt in spawning runs observed in this study may be important for population survival: current spawning runs would experience even lower EPR with lower levels of maturation among age- 1 fish. Further investigations on recruitment relationships and fecundity of rainbow smelt with sampling from a wider geographic range and longer temporal scale are needed to assist management and restoration efforts for rainbow smelt.

Size at age has been reported to decline with increasing latitude for spawning populations of anadromous rainbow smelt (McKenzie, 1964; Pouliot, 2002; Enterline et al., 2012; O'Malley et al., 2017). A large majority of landlocked and anadromous rainbow smelt in populations from eastern Maine northward historically matured at age 2 (Rupp, 1959; McKenzie, 1964; Chen, 1970). Age-1 rainbow smelt are known to spawn at variable rates in U.S. waters of the Gulf of Maine, with higher percentages found in Massachusetts, lower percentages in rivers of western Maine, and near absence in Canadian Maritime provinces (Warfel et al., 1943; McKenzie, 1964; Murawski and Cole, 1978; Pouliot, 2002; Enterline et al., 2012). In Massachusetts, age-2 rainbow smelt have been found to form the predominant cohort in spawning runs, with low, fluctuating percentages observed for age- 1 and age- 3 cohorts, age- 4 fish being uncommon, and fish of ages 5-6 rarely observed (Murawski and Cole, 1978; Lawton et al. ${ }^{8}$ ).

Temperature-related differences in growth rates may be a cause of the decline in proportion of age- 1 rainbow smelt in spawning runs with increasing latitude. Murawski and Cole (1978) back-calculated length at age from scales of rainbow smelt from the Parker River and found close agreement with the actual mean length at age, except for age-1 fish. The lower back-calculated size at age-1 indicates that only larger age- 1 rainbow smelt were recruited to the spawning run. The proportion of age- 1 females was also lower than that of age-1 males in the spawning run, and $Z$ was lower in females than in males (Murawski and Cole, 1978). These findings suggest a trade-off for maturation of rainbow smelt in which fast-growing rainbow smelt that mature in their first year may realize greater lifetime reproductive potential but are exposed to higher mortality than fish that mature later. Both our study and the previous studies of rainbow smelt in Massachusetts found a higher proportion of males than females among age-1 fish in spawning runs (Murawski and Cole, 1978; Sutter, 1980; Lawton et al. ${ }^{8}$ ). The difference between sexes may be related to the longer schedule and larger energy allocation required for oogenesis than for spermatogenesis that has been found in landlocked rainbow smelt (Chen, 1970; Foltz and Norden, 1977).

The maturation schedules of species of Pacific salmon (Oncorhynchus spp.) are likely the best studied of all diadromous species. Natural selection influences maturation strategies in Pacific salmon species as reflected by oocyte size and fecundity (Campbell et al., 2006). Phenotypic differences in egg size and maturation in species of Pacific salmon have been related to water temperature and growth rates, with fast growth, early maturation, high fecundity, and small egg size thought to be a response to lower survival rates (Murray and McPhail, 1988; Kinnison et al., 1998). Further work is needed to determine if the selective pressures on Pacific salmon species are similar to those on anadromous rainbow smelt, given their phylogenetic proximity.

Luey and Adelman (1984) suggested that landlocked populations of rainbow smelt are prone to selective pressures on their reproductive life history because they are small, fast growing, and short-lived. The variability of size and age in spawning populations of anadromous rainbow smelt in the broader geographic region of New England (Chase et al., 2009; Enterline et al., 2012; O’Malley et al., 2017) supports the expectation of a link between growth rates and maturation schedule. Results from genetic analyses of rainbow smelt in our study area by Kovach et al. (2013) provide evidence of gene flow among the 4 locations where fyke nets were deployed and indicate that larval dispersal is most influenced by circulation patterns in the Gulf of Maine and that the circulation patterns were more influential to population genetic structure than natal homing. More information is needed to determine environmental influences, maturation thresholds, and population recruitment consequences across a wider geographic range for the species.

Our data provide evidence of differences in length and suggest that there are differences in growth among populations of rainbow smelt over a small spatial scale. However, the spatial and temporal scales of our data do not allow inferences on interpopulation differences in reproductive life history traits. Further work is needed to determine the nature of phenotypic divergence in reproductive life history of anadromous rainbow smelt across the geographic range of this species and on the population-level consequences of phenotypic plasticity in age and size at maturity. 


\section{Acknowledgments}

We appreciate B. Hoffman for coordinating collection of marine samples and the field and laboratory assistance of intern N. Delphin from Manchester High School, fyke net technicians K. Taylor, C. Woodhead, and K. Magowan, and K. Broomstein, an American Fisheries Society Hutton Scholar. We thank G. Nelson, E. Schultz, G. Skomal, and anonymous reviewers for comments on previous versions. We received financial support through the Sportfish Restoration Act and from the NOAA Protected Species Program.

\section{Literature cited}

Bailey, M. M.

1964. Age, growth, maturity, and sex composition of the American smelt, Osmerus mordax (Mitchill), of western Lake Superior. Trans. Am. Fish. Soc. 93:382-395. Crossref

Campbell, B., B. R. Beckman, W. T. Fairgrieve, J. T. Dickey, and P. Swanson.

2006. Reproductive investment and growth history in female coho salmon. Trans. Am. Fish. Soc. 135:164-173. Crossref

Chase, B. C., M. H. Ayer, and S. P. Elzey.

2009. Rainbow smelt population monitoring and restoration on the Gulf of Maine coast of Massachusetts. Am. Fish. Soc. Symp. 69:899-901.

Chen, M. Y.

1970. Reproduction of American smelt, Osmerus mordax (Mitchill). Ph.D. diss., 254 p. Univ. Waterloo, Ottawa, Canada.

Clayton, G. R.

1976. Reproduction, first year growth, and distribution of anadromous rainbow smelt, Osmerus mordax, in the Parker River and Plum Island Sound estuary, Massachusetts. M.S. thesis, 105 p. Univ. Mass., Amherst, MA.

Crim, L. W., and B. D. Glebe.

1990. Reproduction. In Methods for fish biology (C. B. Schreck and P. B. Moyle, eds.), p. 529-553. Am. Fish. Soc., Bethesda, MD.

Driedzic, W. R., and K. V. Ewart.

2004. Control of glycerol production by rainbow smelt (Osmerus mordax) to provide freeze resistance and allow foraging at low winter temperatures. Comp. Biochem. Physiol. B 139:347-357. Crossref

Driedzic, W. R., and C. E. Short.

2007. Relationship between food availability, glycerol and glycogen levels in low-temperature challenged rainbow smelt (Osmerus mordax). J. Exp. Biol. 210:2866-2872. Crossref

Enterline, C. L., B. C. Chase, J. M. Carloni, and K. E. Mills.

2012. A regional conservation plan for anadromous rainbow smelt in the U.S. Gulf of Maine, 100 p. Maine Dep. Mar. Res., Augusta, ME. [Available from website.]

Evans, D. O., and D. H. Loftus.

1987. Colonization of inland lakes in the Great Lakes region by rainbow smelt, Osmerus mordax: their freshwater niche and effects on indigenous fishes. Can. J. Fish. Aquat. Sci. 44(S2):249-266. Crossref

Federal Register.

2004. Endangered and threatened species; establishment of species of concern list, addition of species to species of concern list, description of factors for identifying species of concern, and revision of candidate species list under the Endangered Species Act. Fed. Regist. 69:19975-19979.

[Available from website.]

Foltz, J. W., and C. R. Norden.

1977. Seasonal changes in food consumption and energy content of smelt (Osmerus mordax) in Lake Michigan. Trans. Am. Fish. Soc. 106:230-234. Crossref

Goode, G. B.

1884. The fisheries and fishery industries of the United States, 881 p. Government Printing Office, Washington, DC.

Gorman, O. T.

2007. Changes in a population of exotic rainbow smelt in Lake Superior: boom to bust, 1974-2005. J. Great Lakes Res. 33:75-90. Crossref

Hare, J. A., D. L. Borggaard, K. D. Friedland, J. Anderson, P. Burns, K. Chu, P. M. Clay, M. J. Collins, P. Cooper, P. S. Fratantoni et al. 2016. Northeast Regional Action Plan-NOAA Fisheries Climate Science Strategy. NOAA Tech. Memo. NMFS-NE-239, 72 p. [Available from website.]

Hixon, M. A., D. W. Johnson, and S. M. Sogard.

2014. BOFFFFs: on the importance of conserving old-growth age structure in fishery populations. ICES J. Mar. Sci. 71: 2171-2185. Crossref

Kendall, W. C.

1926. The smelts. Bull. Bur. Fish. 42:217-375.

Kinnison, M. T., M. J. Unwin, W. K. Hershberger, and T. P. Quinn. 1998. Egg size, fecundity, and development rate of two introduced New Zealand chinook salmon (Oncorhynchus tshawytscha) populations. Can. J. Fish. Aquat. Sci. 55:1946 1953. Crossref

Kircheis, F. W., and J. G. Stanley.

1981. Theory and practice of forage-fish management in New England. Trans. Am. Fish. Soc. 110:729-737. Crossref

Kovach, A. I., T. S. Breton, C. Enterline, and D. L. Berlinsky.

2013. Identifying the spatial scale of population structure in anadromous rainbow smelt (Osmerus mordax). Fish. Res. 141: 95-106. Crossref

Limburg, K. E., and J. R. Waldman.

2009. Dramatic declines in North Atlantic diadromous fishes. BioScience 59:955-965. Crossref

Luey, J. E., and I. R. Adelman.

1984. Stock structure of rainbow smelt in western Lake Superior: population characteristics. Trans. Am. Fish. Soc. 113:709-715. Crossref

Marcotte, A., and J. L. Tremblay.

1948. Notes sur la biologie de l'éperlan (Osmerus mordax Mitchell) de la Province de Québec. Stn. Biol. SaintLaurent Contrib. 18, 107 p. [Available from Direction de la protection de la faune du Bas-Saint-Laurent et de la Gaspésie-Îles-de-la-Madeleine, 92, $2^{\mathrm{e}}$ Rue Ouest, bureau 207, Rimouski, Quebec, Canada G5L 8B3.]

McKenzie, R. A.

1964. Smelt life history and fishery of the Miramichi River, New Brunswick. Fish. Res. Board Can., Bull. 144, 77 p.

Mercado-Silva, N., J. D. Olden, J. T. Maxted, T. R. Hrabik, and M. J. V. Zanden.

2006. Forecasting the spread of invasive rainbow smelt in the Laurentian Great Lakes region of North America. Conserv. Biol. 20:1740-1749. Crossref

Murawski, S. A., and C. F. Cole.

1978. Population dynamics of anadromous rainbow smelt Osmerus mordax, in a Massachusetts river system. Trans. Am. Fish. Soc. 107:535-542. Crossref

Murawski, S. A., G. R. Clayton, R. J. Reed, and C. F. Cole. 1980. Movements of spawning rainbow smelt, Osmerus mordax, in a Massachusetts estuary. Estuaries 3:308-314. Crossref 
Murray, C. B., and J. D. McPhail.

1988. Effect of incubation temperature on the development of five species of Pacific salmon (Oncorhynchus) embryos and alevins. Can. J. Zool. 66:266-273. Crossref

Nelson, G.

2017. Fishmethods: fishery science methods and models. Vers. 1.10-4. [Available from website, accessed March, 2018.]

Nielsen, L. A., and D. L. Johnson (eds). 1983. Fisheries techniques, 732 p. Am. Fish. Soc., Bethesda, MD.

O'Gorman, R., R. A. Bergstedt, and T. H. Eckert.

1987. Prey fish dynamics and salmonine predator growth in Lake Ontario 1974-84. Can. J. Fish. Aquat. Sci. 44(S2): 390-403. Crossref

O’Malley, A. J., C. Enterline, and J. Zydlewski.

2017. Size and age structure of anadromous and landlocked populations of rainbow smelt. North Am. J. Fish. Manage. 37:326-336. Crossref

Pouliot, G.

2002. Dynamique de la population d'éperlans arc-en-ciel (Osmerus mordax) du sud de l'estuaire du Saint-Laurent par l'analyse de cohortes de reproducteurs fréquentant la rivière Fouquette entre 1994 à 2001, 47 p. Société de la faune et des parcs du Québec, Direction de l'aménagement de la faune de la $r$ égion du Bas-Saint-Laurent, Québec, Canada.

$\mathrm{R}$ Core Team.

2016. R: a language and environment for statistical computing. R Foundation for Statistical Computing, Vienna, Austria. [Available from website, accessed May 2016.]

Ricker, W. E.

1975. Computation and interpretation of biological statistics of fish populations. Fish. Res. Board Can., Bull. 191, 382 p.

Roa, R., B. Ernst, and F. Tapia.

1999. Estimation of size at sexual maturity: and evaluation of analytical and resampling procedures. Fish. Bull. 97:570-580.

Rupp, R. S.

1959. Variation in the life history of American smelt in inland waters of Maine. Trans. Am. Fish. Soc. 88:241-252. Crossref

Sayers, R. E., Jr., J. R. Moring, P. R. Johnson, and S. A. Roy. 1989. Importance of rainbow smelt in the winter diet of landlocked Atlantic salmon in four Maine lakes. North Am. J. Fish. Manage. 9:298-302. Crossref
Scott, W. B., and E. J. Crossman.

1973. Freshwater fishes of Canada. Fish. Res. Board Can. Bull. 184, $966 \mathrm{p}$.

Scott, W. B., and M. G. Scott.

1988. Atlantic fishes of Canada. Can. Bull. Fish. Aquat. Sci. $219,731 \mathrm{p}$.

Sokal, R. R., and F. J. Rohlf.

1995. Biometry: the principles and practice of statistics in biological research, $3^{\text {rd }}$ ed., 887 p. W. H. Freeman and Co., New York.

Stritzel Thomson, J. L., D. L. Parrish, S. L. Parker-Stetter, L. G. Rudstam, and P. J. Sullivan.

2011. Growth rates of rainbow smelt in Lake Champlain: effects of density and diet. Ecol. Freshw. Fish 20:503-512. Crossref

Sutter, F. C., III.

1980. Reproductive biology of anadromous rainbow smelt (Osmerus mordax) in the Ipswich Bay area, Massachusetts. M.S. thesis, 49 p. Univ. Mass., Amherst, MA.

Trencia, G., G. Verreault, M. Legault, and V. Tremblay.

2005. L' éperlan arc-en-ciel (Osmerus mordax) anadrome du sud de l'estuaire du Saint-Laurent: une population en voie de désignation comme espèce vulnérable. Nat. Can. 129(1):86-95.

Van Oosten, J.

1937. The dispersal of smelt, Osmerus mordax (Mitchill), in the Great Lakes region. Trans. Am. Fish. Soc. 66:160-171. Crossref

Venables, W. N., and B. D. Ripley.

2002. Modern applied statistics with S, 4th ed., 498 p. Springer, New York.

Verreault, G., G. Trencia, and M. Legault.

2012. The rainbow smelt restoration plan for the St. Lawrence estuary: where are we eight years later? In Fourth North American workshop on rainbow smelt: extended abstract proceedings; Portland, ME, 24-25 January 2011 (C. H. Wood, C. Enterline, K. Mills, B. C. Chase, G. Verreault, J. Fischer, and M. H. Ayer, eds.), 62-64 p. Mass. Div. Mar. Fish. Tech. Rep. TR-51. [Available from website.]

Warfel, H. E., T. P. Frost, and W. H. Jones.

1943. The smelt, Osmerus mordax, in Great Bay, New Hampshire. Trans. Am. Fish. Soc. 72:257-262. Crossref 